\title{
Guarantee of the social rights of children with chronic conditions: reinventing care towards civil rights
}

\author{
Garantia dos direitos sociais das crianças com condições crônicas: reinventando o cuidado para a cidadania
}

Garantía de los derechos sociales de los niños en condiciones crónicas: reinventando el cuidado para la ciudadanía

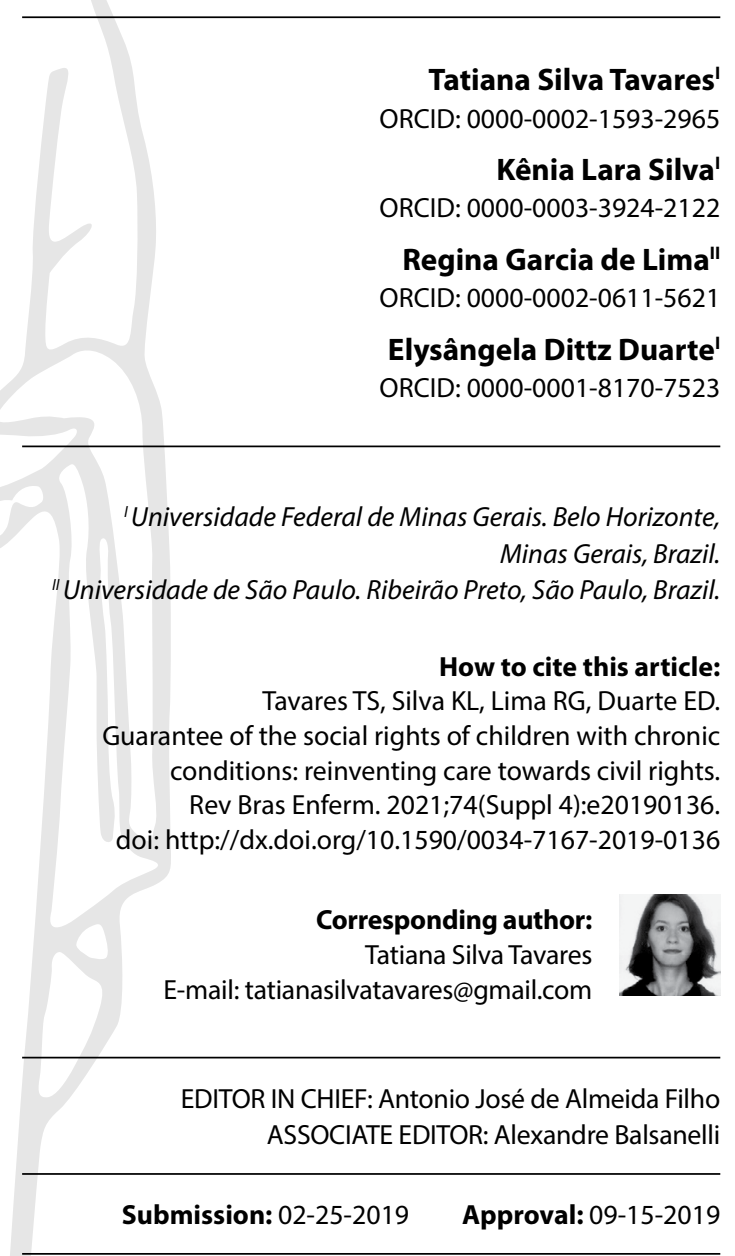

\begin{abstract}
Objective: To analyze the experiences of families in the exercise of the rights of children with chronic conditions in public health, education and social assistance institutions. Method: ethnographic multiple case study, with qualitative approach, following the theoretical approach of Boaventura Santos. Experiences of the families of these children in a city were studied through interviews with family members, managers and professionals from social institutions (35), participant observations in social spaces (13) and creation of eco-maps (3). Critical Discourse Analysis was performed. Results: the offer of services is lower than the demand, and exclusion processes persist. Given the hegemony of neoliberal and normality ideologies, meetings between family members and professionals revealed obstacles to civil rights; however, when these ideologies were challenged, the realization of their rights was enhanced. Final considerations: the care to promote civil rights requires family members, managers and professionals to develop subjectivities that overcome neoliberal and normality ideologies, recognizing these children as subjects of law.
\end{abstract}

Descriptors: Disabled Children; Chronic Disease; Social Welfare; Child Care; Pediatric Nursing

\section{RESUMO}

Objetivo: analisar as experiências das famílias para exercício dos direitos das crianças com condições crônicas nas instituições públicas de saúde, educação e assistência social. Método: estudo de casos múltiplos etnográfico, com abordagem qualitativa e referencial de Boaventura Santos. Foram estudadas experiências das famílias dessas crianças em um município, por meio de entrevistas com familiares, gestores e profissionais das instituições sociais (35), bem como por observações participante nos espaços sociais (13) e elaboração de ecomapas (3). Realizou-se Análise Crítica do Discurso. Resultados: a oferta de atendimento é menor que a demanda e persistem processos de exclusão. Diante da hegemonia das ideologias neoliberal e de normalização, os encontros entre familiares e profissionais revelaram obstáculos à cidadania, porém quando essas ideologias foram contestadas potencializou-se a efetivação dos direitos promulgados. Considerações finais: o cuidado para promover a cidadania exige construção de subjetividades nas práticas de familiares, gestores e profissionais que rompam com as ideologias neoliberal e de normalização, por consequência reconheçam essas crianças como sujeitos de direitos.

Descritores: Crianças com Deficiência; Doença Crônica; Seguridade Social; Cuidado da Criança; Enfermagem Pediátrica.

\section{RESUMEN}

Objetivo: analizar las experiencias de las familias en cuanto el ejercicio de los derechos de los niños en condiciones crónicas de las instituciones públicas de salud, educación y asistencia social. Método: se trata de una investigación etnográfica de casos múltiples, de enfoque cualitativo y referencial de Boaventura Santos, realizada en un municipio con entrevistas a familiares, gestores y profesionales de las instituciones (35), observación de los participantes en los espacios sociales (13) y elaboración de Ecomapas (3); se llevó a cabo el Análisis Crítico del Discurso. Resultados: la oferta del cuidado es inferior a la demanda y persisten los procesos de exclusión. Frente a la hegemonía de las ideologías neoliberales y la normalización, los encuentros entre familiares y profesionales revelaron obstáculos a la ciudadanía; sin embargo, al cuestionarse las ideologías, la efectividad de los derechos promulgados se potencializó. Consideraciones finales: el cuidado para promover la ciudadanía exige construcción de subjetividades en las prácticas de familiares, gestores y profesionales que rompan con las ideologías neoliberales y de normalización y, en consecuencia, reconozcan a esos niños como sujetos de derechos.

Descriptores: Niños con Discapacidad; Enfermedad Crónica; Bienestar Social; Cuidado del Niño; Enfermería Pediátrica. 


\section{INTRODUCTION}

In the last decades, we observed the increase of childhood chronic conditions, partly as a result of political, technological and scientific advances in newborn and child health care ${ }^{(1-3)}$. However, families struggle to provide home care for children with chronic conditions (CCC), to access and use health services and its various sectors, and to obtain medication, special diet and technological equipment ${ }^{(1,4-6)}$. These difficulties may hinder the continuity of care and the fulfillment of the children's needs, compromising the possibilities of autonomy and social participation ${ }^{(1)}$.

Chronic conditions in childhood encompass biological, psychological and cognitive conditions that last or can last for at least one year. These conditions have one or more of the following effects: restrictions in function, activities, or social role compared to children of the same age with no changes in growth and development; reliance on compensatory mechanisms - medication, special diet and technological equipment - or dependence on care due to functional limitations; and service use or need above what is usual for the child's age, in relation to health and education services ${ }^{(2)}$.

The family member responsible for the care of the CCC, usually the mother, is in a constant struggle to ensure that the child's needs are met, developing strategies to access services and supplies in public and supplementary health services ${ }^{(1)}$. This depends on their ability to identify needs and mobilize resources ${ }^{(1,4)}$. The difficulties experienced reveal the transfer of public responsibility for social protection, grounded in the Federal Constitution of 1988, to the private sphere of the children's families. A documentary study on Brazilian legislation has shown that social rights of children with chronic conditions or disabilities are enshrined in the constitution, but the strategies and actions established for this group of children are still incipient and have limited funding, restricting their access $s^{(1,7)}$.

Social rights ensure equal access of all members of a community to basic living standards, provided through institutions in the spheres of education, health and social care. These rights, along with civil and political rights, are elements that make up citizenship, which corresponds to equal membership in a political community ${ }^{(1,8)}$. For an emancipatory citizenship that allows social development without restricting individuality and autonomy ${ }^{(9)}$, the social rights of CCC must guarantee equal social participation while also recognizing their differences and addressing their specific needs ${ }^{(1)}$.

Studies indicate that the current organization of services and actions in the Brazilian context are insufficient to ensure the social rights of $\mathrm{CCC}^{(1,4-5,7)}$. It is assumed that the formulation and implementation of public policies to ensure the social rights of CCC, recognizing their differences, will contribute to their insertion in society as full citizens. Therefore, it is relevant to investigate the experiences of families while trying to ensure access and use of services provided by educational, health and social care institutions, aiming to identify challenges, and contribute to their recognition and to the reformulation of social public policies ${ }^{(1)}$.

\section{OBJECTIVE}

To analyze the experiences of families in the realization of the rights of children with chronic conditions in public health, education and social assistance institutions.

\section{METHOD}

\section{Ethical aspects}

The research was approved by the Research Ethics Committee and the participants signed the Informed Consent Form.

\section{Theoretical and methodological framework}

The 'Sociology of Absences' and the human rights approach proposed by Boaventura Santos were adopted as theoretical and methodological framework. The sociology of absences seeks to demonstrate that what does not exist is, in fact, produced as non-existent, and then disqualified by the rationality of the hegemonic philosophical and scientific knowledge of Western culture. The sociology of absences aims to overcome homogeneous and excluding productions through the identification of other knowledge in social practices (ecology of knowledge) and new articulations between the principles of equality and difference, confronting the association of difference with inequality (ecology of recognition) ${ }^{(9)}$. The sociology of absences can contribute to the social inclusion of CCC, especially those with disabilities, since this inclusion depends on society's ability to predict and incorporate diversity ${ }^{(1)}$.

\section{Type of study}

Ethnographic multiple case study with qualitative approach ${ }^{(10)}$, using COREQ.

\section{Methodological procedures}

Interviews with family members, managers and professionals of social institutions, participant observations in social spaces and creation of ecomaps. The semi-structured guide for the interview with family members included questions about family composition and socioeconomic status, diagnosis of the chronic condition, organization of care, experiences seeking to ensure rights, community participation, access and use of services. The semi-structured guide for the interviews with managers and professionals included questions about training, experience working with CCC, assistance to CCC and their family and relationship with other professionals. The observation guide included aspects that should be contemplated in social spaces and services, such as: accessibility, architectural structure, adaptation of available resources, availability of assistive technologies, organization of activities and actions of participants for the inclusion of CCC, relationships between participants, among others. The ecomap, a diagram of family relationships at a given moment, was used to portray the access of children and their families to services and to social networks ${ }^{(1)}$. The family genogram is placed in the center and the interactions with people, groups or institutions are portrayed around it. The types of these relationships are indicated by lines ${ }^{(11)}$. The guides were previously tested in relation to the objectives of the study. The interviews and observations were conducted by the researcher. Data were recorded in audio through a digital recorder and in written in a field diary ${ }^{(1)}$. 


\section{Study setting}

This study was conducted in the Northern district of Belo Horizonte (Minas Gerais, Southeast Region, Brazil), because this district had a higher distribution of census tracts of high and very high risk, according to the city's Health Vulnerability Index ${ }^{(12)}$.

\section{Data source}

Intentional selection of CCC and their relatives living in the Northern district and managers and professionals of health, education and social assistance services of the city ${ }^{(1)}$.

\section{Data collection and organization}

The data was collected between January 2015 and April 2016. In the exploratory phase, 22 interviews with managers and professionals and 9 observations of events were conducted to understand the municipal and regional context regarding the actions proposed for CCC and the difficulties to the realization of the rights of these children. This phase also allowed selecting the following services for the identification of children: health centers, CRAS (Reference Centers for Social Assistance), Social Protection Service for People with Disabilities (SPSPD), regular school (support team for inclusion of people with disabilities) and Child Protective Service ${ }^{(1)}$. Meetings with the managers and professionals of these services were held in order to present the research and discuss the criteria for the selection of children, which were: having a chronic condition ${ }^{(2)}$ and diverse experiences regarding the pursuit of social rights by the family ${ }^{(1)}$.

A total of 103 children were indicated and the families were reached by telephone. The selection sought to include a variety of indications by district, age group, health condition and access to services ${ }^{(1)}$. The importance of social and cultural aspects in qualitative studies was considered, as these aspects make cases specific and expressed through values, beliefs, opinions, representations, relationships, behaviors and practices, demonstrating the dialectic between the group and the individual ${ }^{(10)}$. Seeveral families could not be reached due to incomplete data informed by the professionals or changes of address and telephone. Initially, 7 family members were contacted and demonstrated interest to participate. A home visit was scheduled with 4 who were immediately available ${ }^{(1)}$.

During the home visit, interviews with family members responsible for the child were conducted, as well as observations of the family routine. After that, biweekly telephone calls were made to receive information about the child (health condition, access and use of services and supplies) and to schedule observations. The experiences of the children and their family in the social spaces and services in their trajectories were observed. Based on these observations in the services, the professionals mentioned by the family as responsible for the care of their child were interviewed. It was necessary to discontinue data collection of two brothers and their mother due to Fragile $X$ Syndrome, a genetic condition reported by the mother, who also had cognitive impairment. This made it difficult to monitor family experiences through interviews and conversations; therefore, it was considered as an exclusion criterium ${ }^{(1)}$.
In the field observation, each of the 3 cases was followed for approximately 4 months, totaling 13 interviews and 5 observations ${ }^{(1)}$. The inclusion of the participants and the progressive data collection, analyzed through the theory related to the object of study, reached a point when the information produced was sufficient to provide recurrence and complementarity of information, and then data collection was interrupted. The following criteria were followed to ensure the rigor of the study ${ }^{(13)}:$ a) prolonged period in the field to grasp the culture, develop trust among participants and verify contradictory information; $b$ ) combination of different sources (family members, managers and professionals) and techniques (interview and observation) in the data collection in order to understand the study object; $c$ ) inclusion of cases with different characteristics to demonstrate the variety of experiences, and review and analysis of data by the counselor and joint counselor.

\section{Data analysis}

The Critical Discourse Analysis, an approach proposed by Fairclough articulating social and linguistic perspectives, was used for data analysis ${ }^{(14)}$. The speeches recorded in the interviews were transcribed and reviewed for their accuracy in relation to the audio. The names of the CCC and their relatives were replaced for the code names they chose. After reading the texts, the researcher selected and coded the sections to be analyzed. MaxQDA software was used for the organization and coding of data. The counselor and joint counselor performed the consensual validation of the coding ${ }^{(1)}$.

Considering linguistics as an instrument for social criticism, the following analytical categories were used: vocabulary for text analysis; interdiscursivity for analysis of discursive practice; and ideological and political effects of discourse for analysis of social practice. The representation meaning of discourses, revealed by values, beliefs and ideas used to represent aspects of the world, was considered. And the identification meaning, referring to the styles, which are related to the processes of self-identification and identification from others. Styles appear through the vocabulary and the categories modality (commitment of actors in relation to what is true or necessary) and evaluation (commitment of actors in relation to what is desirable or undesirable), allowing to analyze the perspective of family members in experiences related to care ${ }^{(1,14)}$.

\section{RESULTS}

In the health sectors of the regional districts of the city, actions directed at CCC were conducted in health centers - by family health teams and the Family Health Support Center (NASF) team -, in the medical specialty centers, in referral units and in rehabilitation centers. As for social assistance, CRAS and SPSPD offered actions for vulnerable and disabled children, respectively. Actions for inclusive education of children with disabilities in municipal schools were developed by the inclusion support team and the Specialized Educational Assistance (AEE) team, with specialized teachers working in inclusive classrooms, promoting educational accessibility for the participation of these children in the school context ${ }^{(1)}$. It is important to note that in the Northern district, socio-economic and sanitation conditions were unfavorable for a significant part of the population ${ }^{(12)}$. 


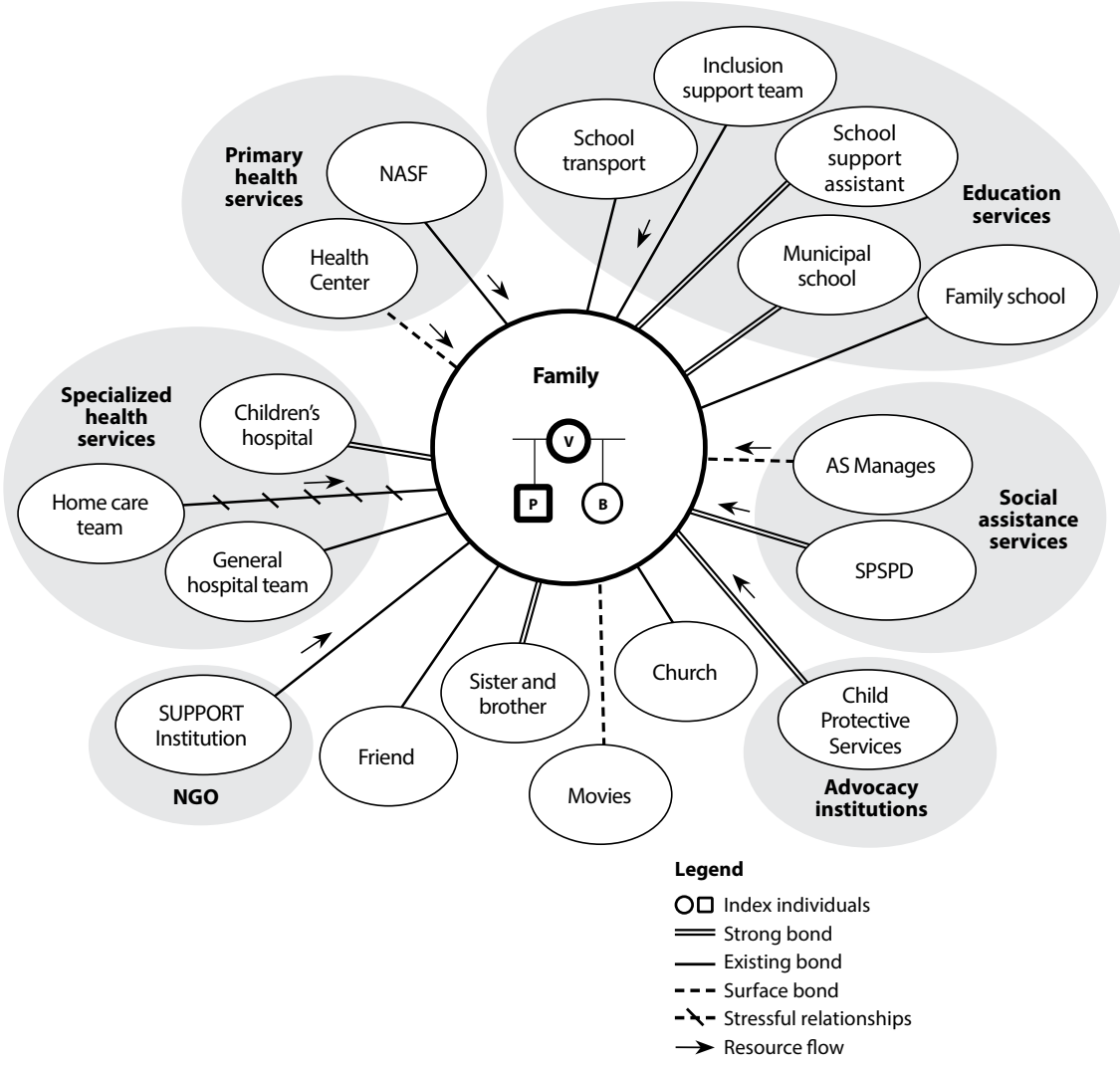

Figure 1 - Ecomap of Pablito and family

The interaction between family members, managers and professionals in their social practices led to diverse experiences of access and use of services, as well as of social participation, which will be shown through the eco-map and the report of the experience of each family. The access of Pablito and his family to services and social networks is represented in the ecomap in Figure 1. Pablito was a 14 years old attentive and communicative boy living with tracheostomy and gastrostomy tubes and atrophied arms and legs, dependent on ventilatory support, requiring support for daily activities and using a wheelchair to get around. He lived with his mother Vitória, 32, and his sister Barbara, 12. Vitória was single, had not completed elementary school and worked as a cleaner, but was unemployed for some time. Pablito and Barbara are children from different partners, both deceased. The family income was composed of the Federal Government Continuous Cash Benefit Programme (BPC), in the amount of one minimum wage ( $R \$ 788.00$ in 2015) and a housing allowance, a R\$ 500.00 housing subsidy provided by City Hall. The family lived in a rented house until December 2015, when they moved to a "shed" that Vitória inherited from the father of one of the children, and the housing allowance was interrupted (1).

Pablito was diagnosed with congenital muscular dystrophy when he was 1 year and 9 months old. Since then, Vitória has organized her daily routine around his care, reducing her work and leisure activities due to the demands of her son. She was the main caregiver and had no family support. In the health sector, primary care provided periodic assistance with a NASF nutritionist and irregular access to medication and care supplies. In specialized health care, when Pablito was approximately 2 years old he was referred to the home care service for children with neuromuscular disease of the state children's hospital, which had a home care team. The assistance in the rehabilitation center was interrupted at the request of this team, due to the difficulty of transportation with the respiratory device. At age 14, Pablito's care was transferred from the state children's hospital to the state general hospital due to his age ${ }^{(1)}$.

In social assistance, the SPSPD team developed actions to strengthen the bond between Pablito and his family. In addition, the service's reference professional advised Vitória about the benefits Pablito was entitled to, such as the BPC, and provided vouchers for the metropolitan public transport, exceptionally for getting assistance in the services provided by the Municipal Health Office. However, when the family changed address, the follow-up in this service was interrupted, as the new residence was located in the area of a CRAS, which should take over the family's follow-up. In the education sector, the inclusion support team offered transportation to the school, a support team to accompany Pablito, and adaptations in the infrastructure to meet his needs. Pablito's support assistant was trained by the home care program staff to perform tracheostomy care ${ }^{(1)}$.

Transportation barriers for getting care and for social participation can be highligted, since Pablito used a wheelchair and relied on technological devices. The use of a respiratory device that needed to be connected to a power source limited his possibilities of leaving the house. This issue was resolved by obtaining a portable battery compatible with the device. However, Vitória mentioned restrictions on making long journeys on public transport with him. Another problem was affording public transport to visit him at the hospital or to go to the Health Department to resolve issues concerning her child ${ }^{(1)}$.

The access and use of services and the acquisition of medication and care supplies were ensured by Vitória's pursuit and the support of regional professionals. Articulation between the different sectors for the defense of Pablito's rights was observed, with special reference to the performance of the child protective services counselor, with the support of the psychologist of the SPSPD and the social assistance manager. This was evidenced in Vitória's speeches about obtaining the battery compatible with the respiratory device and the housing benefit. This benefit was obtained when she had to leave a partner's house due to verbal abuse and threats of violence to her and her children. The BPC was not be enough to pay rent for a property that met the criteria of the home care program while also paying for family expenses. Pablito was in social hospitalization at the state children's hospital for 7 months until they obtained a housing allowance and Vitória was able to rent a house ${ }^{(1)}$.

[...] everyone did something to help Pablito, [...] then everyone gathered, a whole team was formed [...] it's a whole mobilized team. (Vitória) 
Vitória's speeches show her positive evaluation of the joint action of regional professionals, demonstrated by the verbs gather and mobilize. The importance of the support of the child protective services counselor and the psychologist of the SPSPD in guaranteeing the rights of Pablito was also demonstrated. These professionals highlighted the exceptions made in family care due to Pablito's representation, which is an atypical case (SPSPD reference professional) due to his health condition, low life expectancy, and the family's socioeconomic situation. The justifications presented by the professionals for their actions beyond the institutional protocols included discourses of family-centered care, social inclusion and speeches characterizing the woman and children as subjects of law. The discursive practice of professionals revealed a representation about the professional action in the assistance to CCC, with recognition of differences ${ }^{(1)}$ :

It is a case outside our usual line of work, you see, it is a child who did not live in a risk area, who got a housing allowance, it is really an exceptional case, to ensure a family environment.[...] So we had a network meeting [...] and l explained that without this cable he could not go to school and had other damages, psychological damage, you know, he was being prevented from interaction [...]. (Child Protectice Services Counselor)

I analyze her situation [Victoria] in that month, the issues she has to solve, I actually couldn't even provide [transportation vouchers] for health, to tell you the truth, but you know, considering the situation. (SPSPD Psychologist)

Vitória did not highlight any specific difficulty to ensure Pablito's rights, as it was a process with different phases. However, her speeches showed difficulties related to the relationships established with hospital professionals who provided home care. She expressed dissatisfaction with having her responsibility as mother taken away, as she felt that Pablito was being treated as property of the doctor, who took over the responsibility for care decisions. The home care program allowed Pablito to be discharged from the hospital, creating possibilities for social participation. However, the disciplinary mechanisms of the hospital were transferred to the house, as evidenced by Vitória's statement about the prohibition of riding a bus. In general, she denied she was complaining about doctors and moderated her statements, which expressed values about health care. However, this statement highlights the criticism of Vitória, through the use of irony and humor, contesting medical discourse and social roles established between doctor, mother and child. The intertextuality, manifested with the doctor's voice, highlighted the disrespect to her role as a mother ${ }^{(1)}$.

I'm not complaining about any doctor, there was only one thing that Dr. [name] told me that left me like, 'You have a child, you are not responsible for him, your son is at home and it is my responsibility', so it was like I'm the boss of your son, so like, I am just a caregiver of Pablito. [...] it's the same long-time doctors, just like I mentioned, Dr [name], who prohibited me to ride the bus, so there's no problem [laugh] with the doctors, it's all fine. [...] All the programs that I mentioned do not cost me a penny, but if you look closely, you pay a price, not in cash, but a a price, a LOAD. (Vitória)

Over the years, Vitória moved from a posture of subjection to a more demanding and active posture, expressing her values and criticism to the discourse and disciplinary practice of these professionals. The analysis of the identification meaning in Vitória's discursive practice evidenced a social practice of revolt against restricted civil rights; however, her resistance to hegemonic ideologies and biomedical discourse was limited, as she did not know her rights, for example, when she disregarded that she paid for public services through her taxes ${ }^{(1)}$.

The access of Champion and his family to services and social networks is represented in the ecomap in Figure 2. Champion was a 9-year-old boy with a sweet expression, who watched objects attentively or clapped repeatedly; it was difficult to get his attention and he communicated through of facial expressions, grunts and gestures. He needed support for feeding, hygiene, going to the bathroom, and dressing. He walked alone, but had difficulty making transfers and going up or down stairs. He lived with his mother, Happy, 36 old and his sister, Jade, 4. Happy was single and Champion and Jade were children from different partners. She had completed high school and had worked as a saleswoman until the birth of Champion. The family lived in an owned home, which was accessible for Champion, with the exception of the stairs, which did not yet have a handrail. There were no adaptations in the rooms. Happy's mother lives in an independent construction on the same land. Family income was approximately $\mathrm{R} \$ 1,500$, made up of the BPC of one minimum wage ( $R \$ 788,00$ in 2015), and the money provided monthly by Jade's father ${ }^{(1)}$.

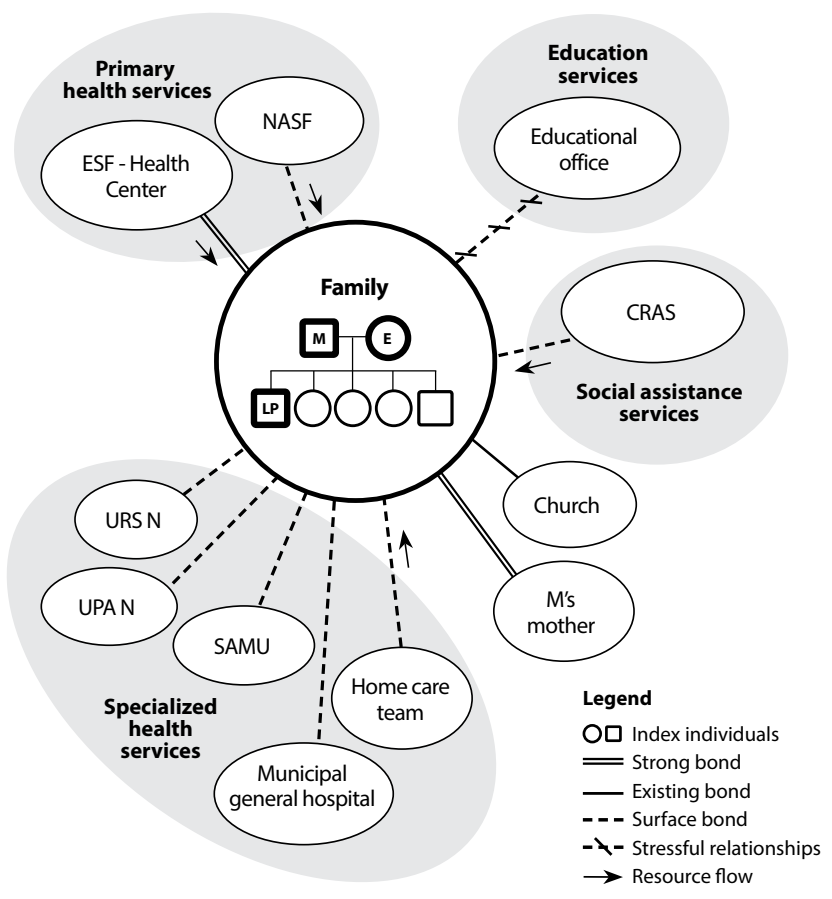

Figure 2 - Ecomap of Champion and his family

Champion was diagnosed with Down syndrome at birth and with autism at 3 years old. After hearing about her son's condition and the assistance he would need, Happy began devoting her life to him, resigned her work, and reorganized her routine for caring for Champion and Jade. She was his main caregiver, and the father was not involved in his care. In the health sector, in primary care, assistance was provided only by the psychiatrist of the complementary mental health team. Happy bought 
Champion's medication, as it was not available at the SUS in the form of solution. In specialized health care, rehabilitation assistance was offered in the clinic of the Association of Parents and Friends of Exceptional Children, linked to the SUS, but the frequency of care was decreasing, and the physiotherapy monitoring had already been interrupted. The SUS provided consultations with a geneticist, and consultations with cardiologist were paid by the health insurance. Happy chose to pay for health insurance for her son when he was young, in order to obtain specialized care ${ }^{(1)}$.

In social assistance, CRAS actions were developed according to the demands of families. Champion had access to the BPC and Fare-Free public transportation. He studied in a municipal school, where he was assisted by a support assistant and by the AEE team. Happy made claims and tried to solve any problem with the regional inclusion support team. Access to sports and leisure services was observed only in this case. Transportation to school and appointments were by car. Happy explained that if she had to use public transportation, she would have difficulty keeping all of her son's appointments, due to travel time and Champion's limitations in staying on the bus or walking longer distances(1).

The assistance at the services and the care supplies for Champion were ensured by Happy's persistent pursuit and enhanced by some professionals, who established a bond with her and Champion. The lack of information about her child's needs and care and the prejudice of society, which limited social inclusion, were highlighted as difficulties. As coping mechanisms, she sought information from non-governmental organizations and support from family and professionals ${ }^{(1)}$.

Regarding the guarantee of social rights, Happy and the teachers mentioned the challenges for the inclusion of Champion in the regular school. Happy understood that her son had a different learning rhythm and that the school adapted the teaching method to his needs. The pedagogical adaptation was accomplished through strategies developed by the AEE teacher, who was trained for this activity. The teacher of the regular school mentioned the lack of information on the subject and the daily experimentation, characterized by uncertainties and aimed at the construction of new paths towards inclusion. The discursive practices of both teachers revealed a defense of inclusive education; however, the speech of the AEE teacher demonstrated a better recognition of differences between students ${ }^{(1)}$.

He, ah, today he goes to school, [...] the pedagogical activities, there is this abacus there that he is crazy about. So there are the toys, there's the way, his way of doing things is different, it is no use wanting/inclusion is he doing everything as the others do? (Happy)

Many of our students, they will not access the subjects as the other students do, the ones called "normal", but, [...] what they can access, what they have the right to access, it's up to us to think [...] we are talking about taking the planning made for that classroom, no matter who is in there, and adapting it to each student's needs, [...] as education professionals, this is what we have to seek all the time, to be able to recognize the individual differences of each student (AEE teacher)

We know thatemotionally I have already achieved a lot. But I wanted to see if on paper, if I will achieve anything, [...] My biggest challenge is this, I want to be able to talk in a way that he can understand. And, there is our lack of information, you know? (Regular school teacher)
In the relationship with the support assistant, there were obstacles to the inclusion of Champion due to the difficulty in dealing with his behavior and the turnover or unavailability of professionals. In days when there was no assistant to accompany him, the principal told Happy that her son could not stay in school. In this situation, Champion's differences were regarded as inferior, which refers to the traditional school discourse. It was evidenced that school inclusion is circumstantial, as its effectiveness depends on the family member's claim and on the attitude of some professionals ${ }^{(1)}$.

[...] he was already sitting in his place and then I turned to her [principal] and told her like 'Willyou send them all away? Is everyone going or is it just my child? What type of inclusion is this? Okay, you want me to take him? I'm taking him now, but I'm leaving here and I'm going to the regional, and I will make a scene, because I do not see this as social inclusion'. (Happy)

Happy was outraged, resorted to the inclusion discourse and claimed his right to stay in school. It is the responsibility of the education system to provide adjustments and support to meet his needs. In her speech, the notion that her child is a subject of law and the struggle for the realization of his rights were verified. The analysis of the identification meaning in Happy's discursive practice revealed a social practice of emancipatory citizenship, marked by the search for information, the dedication to meet the needs of the child and the struggle for his rights and social recognition ${ }^{(1)}$.

Little Prince was a thin 14-year-old boy with postural alterations, limitations of movement of the upper and lower limbs, and increased muscle tone. Sometimes he smiled, reacting to sound and physical stimuli, and grunted. He depended on support for daily activities and used a wheelchair to get around. He lived with his mother, Esther, 31, his father, Miguel, 35, and his three sisters. In the beginning of 2016, another brother was born. His parents had incomplete elementary school; Miguel worked as a freelance salesman and Esther dedicated herself to the care routine. Miguel's mother helped by watching the children when they needed to leave. The family lived in a house built on the plot provided by Miguel's mother, where she also owned her home. The doors and circulation space within the rooms were very narrow, making it difficult to move with a wheelchair on the first floor. There was no ramp to the second floor, only stairs. Miguel carried Little Prince between the rooms. No adaptations were found. Family income consisted of the Federal Government Continuous Cash Benefit in the amount of one minimum wage ( $R \$ 78.00$ in 2015), the child benefit 'Bolsa Familia' and Miguel's income selling CDs/DVDs (approximately R\$500,00) (1).

Little Prince was diagnosed with cerebral palsy due to jaundice complications when he was approximately 3 months old. Later, at about age 10, he developed right hip dislocation. After the diagnosis of their child's chronic condition, the parents organized themselves by sharing the care of Little Prince and the other children. In the health sector, the family team and NASF health team developed actions at the Health Center or at the family's home. The parents had to buy the medications for Little Prince. Despite of the referrals obtained in Primary Care, the waiting time for consultation with the neurologist and the orthopedist was very long. Rehabilitation care was interrupted when Little Prince was approximately ten years old. Access to emergency care at the UPA and SAMU, as well as hospitalization, occurred occasionally due to respiratory failure ${ }^{(1)}$. 


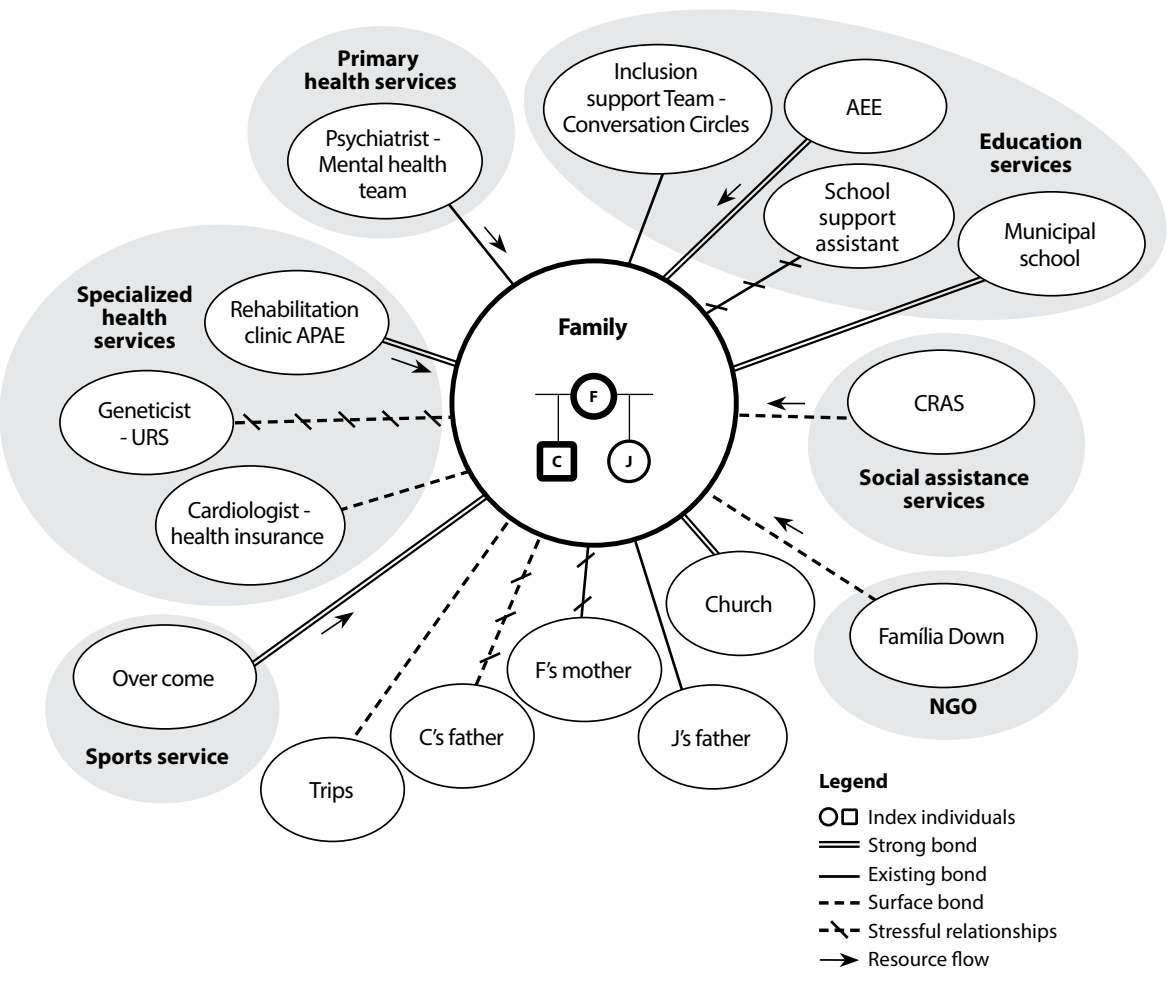

which forced them to prioritize younger children who had a greater likelihood of better functional outcomes ${ }^{(1)}$.

And in the [rehabilitation] clinics when the children reach at the age of $10 . . .9$ years, they are discharged, because from then on, it's only maintenance. So, parents are already known how to do the exercises... and all.... So, it's just maintaining that. There is no more GAAIN, the real gain is the beginning, right? (NASF Physical Therapist)

The responsibility for the exercises was then transferred to the parents. Miguel understood that this logic also influenced the orthopedists' choice of not performing hip surgery. He believed that surgery could have contributed to reducing the child's discomfort and pain and disagreed with the decision. The values presented by parents in relation to the desirable practice refer to the discourse of humanization and palliative care ${ }^{(1)}$.
Figure 3 - Ecomap of Little Prince and his family

In social assistance, CRAS actions were developed according to the demands of families. Little Prince's family had access to the BPC and the Bolsa Familia. There were difficulties in the education sector, for example, regular school struggled to meet his needs and to adapt activities to include him in the classroom. As the pain of his hip dislocation worsened when he was in the wheelchair, his parents chose to remove him from school. They reported obstacles to traveling with their children on public transport, since he used a wheelchair and experienced pain and agitation, which restricted leaving with the child to services and to leisure activities. Therefore, the child spent most of the time in the room watching television ${ }^{(1)}$.

In their search to meet the needs of their children, the parents received little support from institutional and community networks; support came mainly from primary care professionals, as evidenced in the ecomap. Family members highlighted the concern and distress they experienced when the child needed to be hospitalized for respiratory failure. Regarding the guarantee of the social rights of Little Prince, several barriers were identified, especially for access to specialized health services. The speeches of parents, managers and primary care professionals highlighted: inefficient integration between the teams of the different services; the NASF team was responsible for the care of an excessive number of families and did not have a speech therapist; insufficient resources for the care demand in specialized services, especially regarding pediatric professionals; little counter reference to primary care; distant services, associated with the difficulty of traveling with the wheelchair in public transport; unavailability of a transport provided by the health sector for the displacement of children with disabilities to rehabilitation or specialty services. In addition, specialized services commonly discharged children with disabilities at approximately 10 years of age, due to the limited offer of rehabilitation services,
He [the orthopedist] said that he would not need surgery because he is wheelchair-bound anyway [...] you see that the person is in pain, with deformities in the spine, but they do not do it, they are like, the person will not evolve, so why will I do a surgery just to improve it a tiny bit? (Miguel).

We had to have a follow-up, [...] like in his case, he can't go out to do physical therapy, they had to send a person, to come do physical therapy, to help us, right? (Esther).

Little Prince's pain caused progressive restrictions in his quality of life and social participation, disturbing his parents. The physical therapist and the doctor mentioned the importance of offering emotional support to the family in this situation, but the doctor's statement revealed contradictions regarding the parents' report about the Little Prince's quality of life ${ }^{(1)}$.

So it is a situation in which we will not have a significant improvement, right, but we always have to try to improve his quality of life [...] So, he is very well cared for, and he has a good quality of life, due to the care he receives in the family, and the family is always in contact, so it is a good situation, well, I mean, a comfortable situation, right. [...] I believe that the most difficult thing is the issue of parents, the comfort, tranquility of parents, because l believe that parents always want the best, they want the cure, the improvement. So sometimes it is more difficult for us to be able to control this anxiety, this yearning of parents, regarding the child's suffering or the child's condition (Family Health Team Doctor)

The professional conduct directed to cure or functional development, based on normality criteria of biomedical discourse, evidenced the predominance of the ideology of normalization. This restricts the perspective of actions for a teenager with cerebral palsy and declining functions and body strength. The parents had 
a vague notion about their child's rights as a citizen. The analysis of the identification meaning in the discursive practice of Miguel and Esther revealed a social practice of search for child care, with insufficient capacity to mobilize resources. As parents and caregivers, they expressed their indignation, but their identities still remained subjected to cognitive-instrumental rationality and to the ideology of normalization that leads to the social exclusion of Little Prince ${ }^{(1)}$.

\section{DISCUSSION}

The processes of institutionalization and subjectivation of the rights of CCC presented obstacles in relation to the implementation of social policies. Institutionalization is related to institutional structure, including knowledge and practices, to implement health policies ${ }^{(15)}$. Regarding this process, the organization of services and actions in the city complied with national legislation ${ }^{(7)}$ and presented innovative solutions to implement social policies, but had insufficient supplies to meet the demands ${ }^{(1)}$.

In the health sector, restrictions on the care provided by NASF teams, in primary care, by medical specialties and in rehabilitation in specialized care were observed. The integration between primary and specialized care was also restricted. Continuous medications used by CCC were not available in the SUS pharmacy. In addition, there was no available transportation to health services that were not offered in the district of residence, such as rehabilitation services. In the social assistance sector, the number of CRAS units was lower than the required considering the areas of vulnerability of the district, and the teams did not offer systematic actions for children with disabilities and their families, acting only according to the demand. The actions of the SPSPD included children with disabilities, but the teams did not work in the areas covered by the CRAS. In education, the number of vehicles for transporting students with reduced mobility to school was insufficient. It is worth noting that the social assistance and education services developed strategies aimed at children with disabilities, not encompassing children with chronic diseases. Due to the same logic in the transport sector, children with chronic conditions were not entitled to free-fare transportation, although they often had to travel to different services. In the area of sports and leisure, there was only one sports center for people with disabilities in the entire city, which was insignificant in relation to the demand ${ }^{(1)}$.

Subjectivation refers to the constitution of political subjects through the construction of individual and group identities that overcome alienation, through strategies of social transformation and rupture with relations of oppression ${ }^{(15)}$. Regarding this process, the discursive and social practices of managers and professionals revealed difficulties related to values, discourses and relationships that reproduce oppression: a) the biomedical discourse and disciplinary power in the definition of care plans centered on disease and body control through surveillance, perpetuating the logic of hospital care in the community; b) the welfare discourse, evidenced by the reduction of social assistance for providing living conditions; $c$ ) and the logic of normality associated with cognitive-instrumental rationality, which prioritized the care of children with higher probability of cure or functional development and restricted the inclusion of those who were out of the norm in health and education services. In the discursive and social practices of family members, the difficulties for the constitution of political subjects were related to the burden of care, restricted social support and poor access to information ${ }^{(1)}$.

Several of these obstacles have been reported in national studies on health care, social assistance and education of $\operatorname{CCC}^{(4-5,16-21)}$. The results of this study indicated, in the socioeconomic perspective, the persistence of insufficient structure and resources to implement social policies due to underfunding, restricting the offer and quality of care. The reduction of state funding is typical of a minimal state and demonstrated the subordination of social policies to the hegemony of neoliberal ideology and its production logic. In the cultural and social areas, the logic of social classification was maintained, which leads to processes of exclusion of CCC, especially those with disabilities, regarded as inferior by the normality criteria $^{(1,9)}$. Although the legal recognition of CCC is guaranteed in the legislation ${ }^{(7)}$, in reality, the predominant neoliberal and normality ideologies compromise the recognition of these children in social relations and the economic and social redistribution ${ }^{(1,9)}$.

In the sociology of absences, the ecology of recognition opposes the logic of social classification of capitalism ${ }^{(9)}$, which disqualifies CCC and attributes an inferior value to difference, leading to inequality ${ }^{(1,9)}$. This conflict was demonstrated through the struggle of family members for the recognition of these children and for their social emancipation, fighting oppression and domination ${ }^{(1)}$. Studies on family resilience in crisis situations, such as the news of the child's chronic condition, indicated the influence of several factors on family adaptation ${ }^{(22)}$. According to the variations of these factors, each family participating in this study experienced a unique adaptation process. In the cases of Vitória and Happy, their pursuit led to the development of strategies to ensure the rights of their children. It is worth highlighting social support as a factor that contributed to adaptation when provided by state institutions, interpersonal relationships and sharing of information ${ }^{(1)}$.

The children in this study are included in the inequality and exclusion systems due to the socioeconomic conditions of the families and the deviation from the normality criteria ${ }^{(1,9)}$. With no actions for the equal access to social institutions, for the development of family abilities and for the social inclusion of these children, the provision of the cash benefit programme only allows integration by consumption ${ }^{(15)}$. Access to information is one of the fundamental conditions to enable participation, avoiding a situation of restricted civil rights ${ }^{(23)}$, and it could be provided by professionals of social institutions, increasing the social capital of these families, as verified in relation to Vitória and Happy. In these cases, the professionals contributed with information about the institutions and the resources of the network, which provided or enhanced conditions of participation and fight for rights, even if the family members did not fully understand their legal rights ${ }^{(1)}$.

\section{Limitations of the study}

The cases studied show experiences related to meetings between family members, managers and professionals in a given space and time. Each case was individually analyzed, and then compared with the others, which allowed transferring the analyzes to other contexts, considering the characteristics of the scenario and the population ${ }^{(1)}$. Considering the proposal of 
in-depth research and ethnographic case study, the number of participants does not allow generalizations of the results. therefore, other studies on the theme should be developed.

\section{Contributions to the areas of nursing, health or public policies}

It is necessary to prioritize the implementation of social policies to ensure the rights of CCC and to provide adequate financing to expand the offer of services according to the demand and the intersectoral actions. In order to improve the quality of care, it is important to overcome neoliberal and normality ideologies in the training of professionals working in health, social care and education institutions. It is also important to provide information to family members of CCC, to allow the constitution of political subjects who can fight for the rights of these children. Regarding the practice of managers and professionals, including nursing professionals, it is essential to find ways for a greater participation in the care of CCC, considering the recognition of differences and of their specific needs ${ }^{(1)}$.

\section{FINAL CONSIDERATIONS}

The interaction between family members, managers and professionals in social practices led to different characteristics of access and use of social institutions and of social participation of CCC, according to the pursuit of the participants for the recognition of these children and the exercise of their rights. The meetings between family members, managers and professionals, when guided by the ideology of human rights and the discourse of recognition of differences, enhanced the exercise of the rights established in the legislation; however, when these interactions were associated with an ideology of normality and a biomedical discourse, they led to obstacles to emancipatory citizenship. In this perspective, the full exercise of the rights of CCC requires access and effective use of public services, recognition of differences in care and continuity of care. In order to promote civil rights, the care provided to CCC requires family members, managers and professionals to develop subjectivities that overcome hegemonic ideologies and recognize these children as subjects of law, enabling them to defend their well-being and social inclusion.

\section{REFERENCES}

1. Tavares TS. O cuidado às crianças com condições crônicas e a garantia de seus direitos sociais [Tese]. Belo Horizonte: Universidade Federal de Minas Gerais, 2017. 221 p.

2. Stein RE. The 1990s a decade of change in understanding children with ongoing conditions. Arch Pediatr Adolesc Med. 2011;165(10):880-3. https://doi.org/10.1001/archpediatrics.2011.165

3. Glass HC, Costarino AT, Stayer SA, Brett CM, Cladis F, Davis PJ. Outcomes for extremely premature infants. Anesth Analg. 2015;120(6):133751. https://doi.org/10.1213/ANE.0000000000000705

4. Tavares TS, Sena RR, Duarte ED. Implications for nursing care concerning children discharged from a neonatal unit with chronic conditions. Rev Rene. 2016;17(5):659-67. https://doi.org/10.15253/2175-6783.2016000500011

5. Nóbrega VM, Silva MEA, Fernandes LTB, Viera CS, Reichert APS, Collet N. Chronic disease in childhood and adolescence: continuity of care in the Health Care Network. Rev Esc Enferm USP. 2017;51:e03226. https://doi.org/10.1590/s1980-220x2016042503226

6. Woodgate RL, Edwards M, Ripat JD, Borton B, Rempel G. Intense parenting: qualitative study detailing the experiences of parenting children with complex care needs. BMC Pediatr. 2015;15:197. https://doi.org/10.1186/s12887-015-0514-5

7. Tavares TS, Duarte ED, Sena RR. Social rights of children with chronic conditions: a critical analysis of Brazilian public policies. Esc Anna Nery. 2017;21(4):e20160382. https://doi.org/10.1590/2177-9465-ean-2016-0382

8. Marshall TH. Cidadania, classe social e status. Rio de Janeiro: Zahar, 1967. 220 p.

9. Santos BS. A gramática do tempo: para uma nova cultura política. São Paulo: Cortez, 2010.511 p.

10. Stake RE. The art of case study research. Thousand Oaks: SAGE, 1995. 175 p.

11. Nascimento LC, Rocha SMM, Hayes VE. Contribuições do genograma e do ecomapa para o estudo de famílias em enfermagem pediátrica. Texto Contexto Enferm. 2005;14(2):280-86. https://doi.org/10.1590/S0104-07072005000200017

12. Prefeitura Municipal de Belo Horizonte. Índice de Vulnerabilidade Social 2012. Belo Horizonte: $\mathrm{PBH} ; 2012$.

13. Guba EG. Criteria for assessing the trustworthiness of naturalistic inquiries. ECTJ. 1981;29(2):75-92.

14. Fairclough N. Analysing discourse: textual analysis for social research. New York: Routledge; 2003. 270 p.

15. Fleury S. Educação Popular e questões de poder. Interface (Botucatu). 2014;18(Suppl 2):1489-92. https://doi.org/10.1590/1807-57622013.0607

16. Vaz EMC, Collet N, Cursino EG, Forte FDS, Magalhães RKBP, Reichert APS. Care coordination in Health Care for the child/adolescent in chronic condition. Rev Bras Enferm. 2018;71(Suppl 6):2612-19. https://doi.org/10.1590/0034-7167-2017-0787

17. Nóbrega VM, Reichert APS, Viera CS, Collet N. Longitudinality and continuity of care for children and adolescents with chronic diseases. Esc Anna Nery. 2015;19(4):656-63. https://doi.org/10.5935/1414-8145.20150088

18. Cabral IE, Moraes JRMM. Family caregivers articulating the social network of a child with special health care needs. Rev Bras Enferm. 2015;68(6):1078-85. https://doi.org/10.1590/0034-7167.2015680612i

19. Duarte ED, Silva KL, Tavares TS, Nishimoto CLJ, Silva PM, Sena RR. Care of children with a chronic condition in primary care: challenges to the healthcare model. Texto Contexto Enferm. 2015;24(4):1009-17. https://doi.org/10.1590/0104-0707201500003040014 
20. Batista Jr JR, Sato DTB. Educação inclusiva no Brasil: discursos e práticas de letramento. Discurso Soc [Internet]. 2015;9(Spec No 1-2):201-21. Available from: http://www.dissoc.org/ediciones/v09n01-2/DS9(1-2)Ribamar\&Borges.pdf

21. Costa NR, Marcelino MA, Duarte CMR, Uhr D. Social protection and people with disabilities in Brazil. Ciênc Saúde Coletiva. 2016;21(10):303747. https://doi.org/10.1590/1413-812320152110.18292016

22. Hall HR, Neely-Barnes SL, Graff JC, Krcek TE, Roberts RJ, Hankins JS. Parental stress in families of children with a genetic disorder / disability and the resiliency model of family stress adjustment and adaptation. Issues Compr Pediatr Nurs. 2012;35(1):24-44. https://doi.org/10.3109/0 1460862.2012 .646479

23. Santos BS. Renovar a teoria crítica e reinventar a emancipação social. São Paulo: Boitempo, 2007. 126p.

\section{ERRATUM}

Article "Guarantee of the social rights of children with chronic conditions: reinventing care towards civil rights", with number of DOI: https://doi.org/10.1590/0034-7167-2019-0136, published in the journal Revista Brasileira de Enfermagem, 74(Suppl 4): e20190136, on the front page. Figures 2 and 3 are in reverse order, keeping only the titles.

Where did you see:

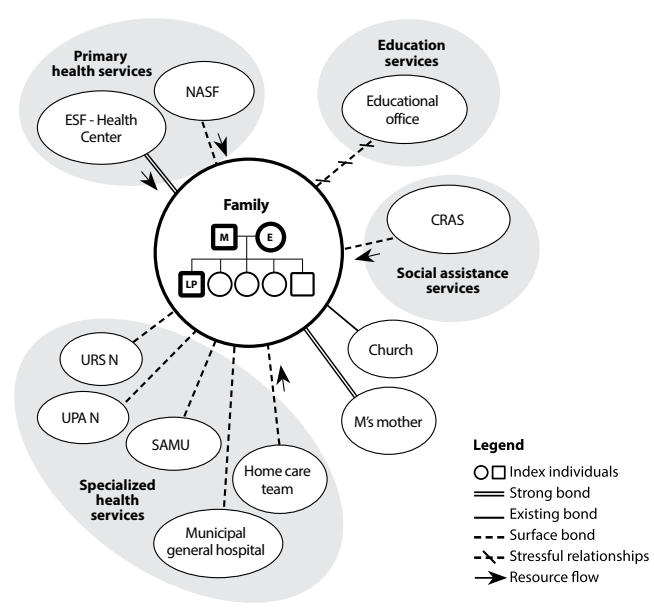

Figure 2 - Ecomap of Champion and his family

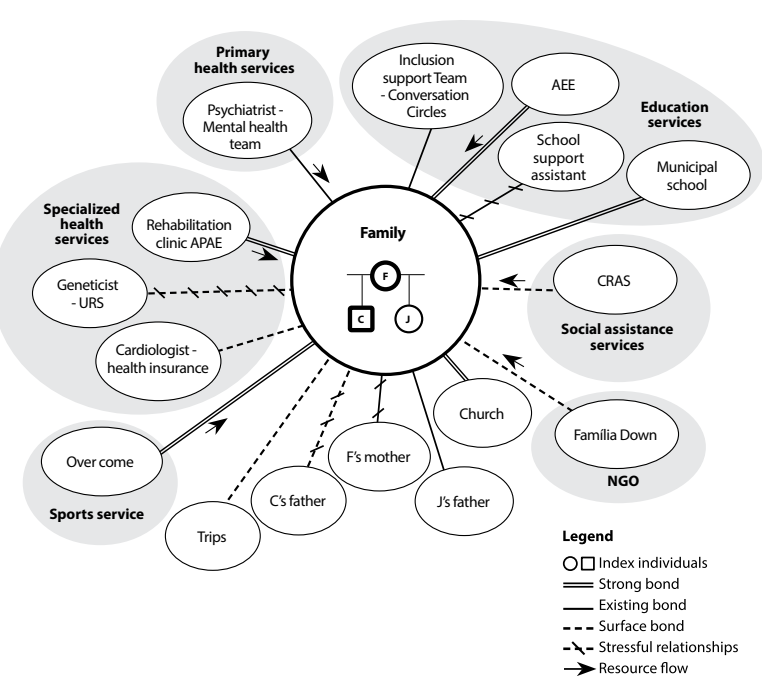

Figure 3 - Ecomap of Little Prince and his family

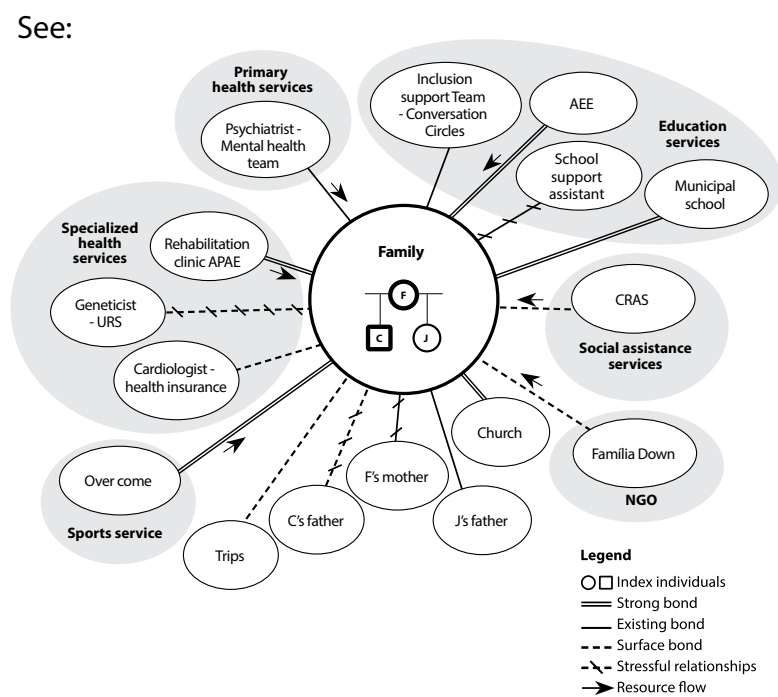

Figure 2 - Ecomap of Champion and his family

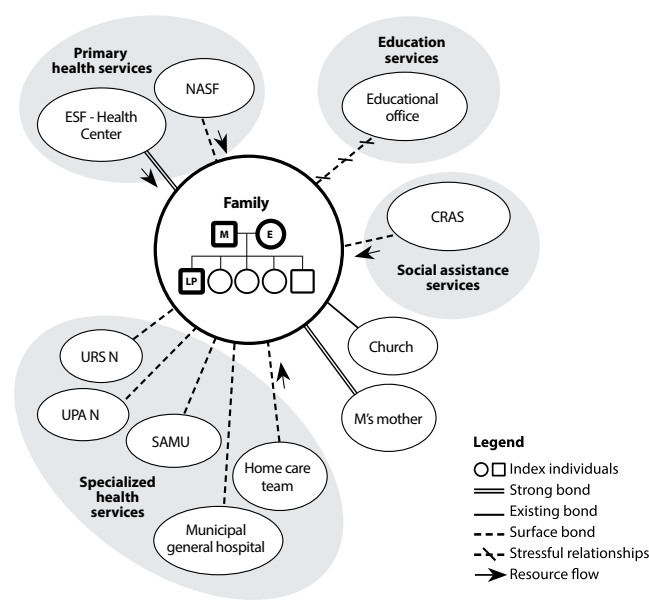

Figure 3 - Ecomap of Little Prince and his family 